Research Article

www.ijrap.net

\title{
EFFECTIVE MACROMUTANTS INDUCED THROUGH CHEMICAL MUTAGENESIS IN B-67 CULTIVAR OF SESAMUM INDICUM L.
}

\author{
Dey Sengupta Sonali * \\ Department of Botany, A.P.C. Roy Govt. College, Siliguri, West Bengal, India
}

Received on: 24/03/17 Accepted on: 02/06/17

\begin{abstract}
*Corresponding author
E-mail: sonalidey71@gmail.com
\end{abstract}

DOI: 10.7897/2277-4343.083151

\begin{abstract}
Comparison between (C.D. at 5\% level) the mean values of control and 21 different true breeding macromutant ( induced by chemical mutagenesis) lines of sesame (Sesamum indicum L.) is made based on 10 quantitative parameters (plant height, number of primary branches/plant, total branches/plant, distance from base to first branching, number of capsules on the main axis, total capsules/plant, capsule len gth, seeds/capsule, 100seed weight and seed yield/plant ) at $\mathrm{M}_{4}$ (plant types grown in randomized block design with 3 replications). Results indicate that none of the mutant show superiority over control for all the traits under study but few of them demonstrate betterment than control in some traits. Some of the true breeding macromutants are closely correspond to the ideotype being looked for in the species.
\end{abstract}

Keywords: Sesamum indicum L., macromutants, chemical mutagenesis, quantitative traits

\section{INTRODUCTION}

Sesamum indicum L. (Family: Pedaliaceae; common name sesame), an oil yielding crop of commerce also possesses immense therapeutic uses. The leaves and roots are used as preventive measure for boils, carbuncle, menstrual irregularities, blood dysentery, poly-urea, stomach trouble, migraine, serious burns and alopecia ${ }^{1}$. Sesame seeds are considered as emollient, diuretic, lactagogue and as nourishing tonic besides been helpful for remedy of piles, cough and ulcer ${ }^{2}$. Morton ${ }^{3}$ suggested that the mucilage obtained from leaves following boiling in water is used as a remedy of chronic diarrhea and intestinal and urinary disorder apart from its application in ophthalmic and skin diseases (flowers). Thus, it seems that the entire plant is therapeutically significant. Considering the potential importance of sesame both as oil yielding crop and as medicinal plant species, it is of utmost significance to keep the species under sustainable cultivation in regions conductive for its growth.

Being self pollinated, sesame offer little scope of genetic variation. Induction of mutation widens gene pool in a short span of time and can offer scope for raising desirable plant ideotypes being looked for in the species. With the view to it, the present research investigation describes the agronomic traits of true breeding induced macromutants in B-67 (most adaptive cultivar in West Bengal plains ${ }^{4,5}$ ) cultivar of $S$. indicum with an objective to screen desirable plant type mutants. Plant type mutations have been reported in different plant species $6,7,8$ including sesame ${ }^{9,10,11}$.

\section{MATERIAL AND METHOD}

Seeds of B-67 cultivar of sesame (moisture content-6.446\%) were obtained from Pulse and Oil Seed Research Station, Berhampur, West Bengal. Seeds were treated with different doses $(0.25 \%, 0.50 \%$, and $1.0 \%$ for 2,4 and 6 hours $)$ of chemical mutagens namely, ethyl methane sulphonate (EMS), di ethyl sulphate (DES), nitrous acid $\left(\mathrm{HNO}_{2}\right)$, hydroxylamine $\left(\mathrm{NH}_{2} \mathrm{OH}\right)$, sodium azide $\left(\mathrm{NaN}_{3}\right)$, hydrogen peroxide $\left(\mathrm{H}_{2} \mathrm{O}_{2}\right)$ and dimethyl sulphoxide (DMSO). Hundred seeds were treated in each lot of treatment. Control set was uniformly maintained. Control and treated seeds were sown in the experimental field plots of Department of Botany, Kalyani University during the months of February to June to raise $M_{1}$ generation. Distance between plants $(20 \mathrm{~cm})$ and rows $(25 \mathrm{~cm})$ was uniformly maintained. No fertilizer application was made during any time of the growth period.

First formed flower from each plant was selfed and seeds were kept in separate packets. Seeds were sown at $\mathbf{M}_{2}$ in plant to progeny. Macromutants were screened from seedling to maturity. First formed flower of each mutant was selfed and seeds were stored in desiccators. Selfed seeds of macromutants were sown at $\mathrm{M}_{3}$ and subsequently true breeding mutants were raised at $\mathbf{M}_{4}$. Each mutant plant type was grown in randomized block design ( $3 \mathrm{~m} \times 1.5 \mathrm{~m}$, three rows in each plot) with three replications. Observations were made from 5 randomly selected plants from each row and a total of 45 plants in control and in each mutant plant type were assessed for different phenotypic variables. Phenotypic variables namely, plant height, number of primary branches/plant, total branches/plant, distance from base to first branching, number of capsules on the main axis, total capsules/plant, capsule length, seeds/capsule,100-seed weight and seed yield/plant were studied. Results obtained were statistically analyzed.

\section{RESULT AND DISCUSSION}

Results indicate (Table1) that none of the mutant exhibit superiority over control for all the traits under study but few of them show betterment in some traits. As compared to control, plant height is found to increase significantly in broad leaf, thick leaf, cluster flower, late flowering, small flower and large seeded mutant; while, number of primary branches/plant and total branches/plant enhance significantly in cluster flower mutant. Positive and significant response over control in relation to distance from base to first branching is noted in viridis, thick leaf, diffused branching and funnel plant types. 
Table 1: Analysis of quantitative characters in control and in different macromutant lines

\begin{tabular}{|c|c|c|c|c|c|}
\hline Plant Types & $\begin{array}{l}\text { Plant height (cm) } \\
{[\text { Mean } \pm \text { S.E. }]}\end{array}$ & $\begin{array}{l}\text { No. of primary } \\
\text { branches } \\
\text { /plant } \\
\text { (Mean } \pm \text { S.E.) }\end{array}$ & $\begin{array}{l}\text { No. of total } \\
\text { branches/ } \\
\text { plant } \\
\text { (Mean } \pm \text { S.E.) }\end{array}$ & $\begin{array}{l}\text { Distance }(\mathbf{c m}) \text { from } \\
\text { base to first } \\
\text { branching } \\
(\text { Mean } \pm \text { S.E. })\end{array}$ & $\begin{array}{l}\text { No. of capsules on } \\
\text { the main axis } \\
\text { (Mean } \pm \text { S.E.) }\end{array}$ \\
\hline Control & $77.74 \pm 1.91$ & $2.83 \pm 0.22$ & $2.83 \pm 0.22$ & $28.42 \pm 1.10$ & $17.48 \pm 1.05$ \\
\hline Viridis & $37.77 \pm 1.89$ & $0.67 \pm 0.18$ & $0.67 \pm 0.18$ & $11.73 \pm 2.93$ & $3.20 \pm 0.23$ \\
\hline Broad leaf & $93.50 \pm 2.02$ & $3.75 \pm 0.65$ & $3.75 \pm 0.65$ & $21.13 \pm 2.06$ & $26.25 \pm 7.28$ \\
\hline Thick leaf & $91.88 \pm 4.13$ & $2.55 \pm 0.42$ & $2.67 \pm 0.42$ & $17.80 \pm 2.63$ & $27.00 \pm 3.26$ \\
\hline Unforked narrow leaf & $76.70 \pm 2.23$ & $2.96 \pm 0.31$ & $2.96 \pm 0.31$ & $18.64 \pm 0.70$ & $22.70 \pm 1.50$ \\
\hline Dwarf & $50.63 \pm 2.22$ & $1.88 \pm 0.20$ & $1.88 \pm 0.20$ & $19.90 \pm 1.23$ & $10.13 \pm 1.10$ \\
\hline Diffused branching & $100.45 \pm 2.76$ & $3.92 \pm 0.22$ & $4.55 \pm 0.37$ & $17.49 \pm 1.09$ & $23.25 \pm 2.48$ \\
\hline Funnel & $82.06 \pm 3.74$ & $2.63 \pm 0.30$ & $2.88 \pm 0.45$ & $15.65 \pm 1.09$ & $22.25 \pm 2.30$ \\
\hline Cluster flower & $117.79 \pm 2.83$ & $5.00 \pm 0.46$ & $7.83 \pm 1.04$ & $33.13 \pm 5.35$ & $18.92 \pm 1.52$ \\
\hline Early flowering & $70.90 \pm 2.34$ & $3.13 \pm 0.23$ & $3.13 \pm 0.23$ & $20.49 \pm 0.78$ & $17.27 \pm 1.21$ \\
\hline Late flowering & $110.64 \pm 5.34$ & $3.57 \pm 0.28$ & $3.86 \pm 0.37$ & $57.46 \pm 3.01$ & $19.71 \pm 1.40$ \\
\hline Small flower & $101.33 \pm 2.05$ & $2.23 \pm 0.28$ & $2.23 \pm 0.28$ & $28.30 \pm 2.40$ & $22.23 \pm 0.99$ \\
\hline White flower & $65.32 \pm 4.01$ & $1.87 \pm 0.21$ & $2.40 \pm 0.20$ & $18.60 \pm 1.60$ & $8.03 \pm 0.94$ \\
\hline Globular fruit & $77.29 \pm 5.14$ & $1.86 \pm 0.31$ & $2.00 \pm 0.40$ & $23.17 \pm 2.92$ & $18.43 \pm 2.88$ \\
\hline Nonshattering capsule & $88.09 \pm 2.78$ & $2.17 \pm 0.24$ & $2.17 \pm 0.24$ & $27.80 \pm 2.55$ & $16.91 \pm 0.94$ \\
\hline Elongated fruit & $84.40 \pm 2.09$ & $2.60 \pm 0.78$ & $2.60 \pm 0.78$ & $23.80 \pm 5.42$ & $18.00 \pm 2.17$ \\
\hline $\begin{array}{l}\text { Reddish brown seed } \\
\text { coat I }\end{array}$ & $60.53 \pm 2.02$ & $2.73 \pm 0.20$ & $2.73 \pm 0.20$ & $30.48 \pm 1.21$ & $6.60 \pm 0.74$ \\
\hline $\begin{array}{l}\text { Reddish brown seed } \\
\text { coat II }\end{array}$ & $66.94 \pm 2.42$ & $2.42 \pm 0.49$ & $2.42 \pm 0.49$ & $20.53 \pm 3.26$ & $12.57 \pm 0.91$ \\
\hline $\begin{array}{l}\text { Dark Reddish brown } \\
\text { seed coat I }\end{array}$ & $77.35 \pm 1.22$ & $2.75 \pm 0.20$ & $2.75 \pm 0.20$ & $24.69 \pm 0.73$ & $21.10 \pm 0.72$ \\
\hline $\begin{array}{l}\text { Dark Reddish brown } \\
\text { seed coat II }\end{array}$ & $65.87 \pm 1.92$ & $2.15 \pm 0.26$ & $2.15 \pm 0.26$ & $22.33 \pm 1.35$ & $13.05 \pm 0.91$ \\
\hline Bold seeded & $85.15 \pm 2.22$ & $1.88 \pm 0.24$ & $1.88 \pm 0.24$ & $22.16 \pm 2.65$ & $17.81 \pm 1.00$ \\
\hline Large seeded & $95.10 \pm 2.74$ & $1.90 \pm 0.19$ & $1.90 \pm 0.19$ & $29.02 \pm 2.50$ & $20.19 \pm 1.23$ \\
\hline C.D. at $5 \%$ level & 10.74 & 1.64 & 3.05 & 10.94 & 9.83 \\
\hline
\end{tabular}

\begin{tabular}{|c|c|c|c|c|c|}
\hline Plant Types & $\begin{array}{l}\text { No. of capsules/ } \\
\text { plant } \\
\text { (Mean } \pm \text { S.E.) }\end{array}$ & $\begin{array}{l}\text { Capsule length }(\mathrm{cm}) / \\
\text { plant } \\
\text { (Mean } \pm \text { S.E.) }\end{array}$ & $\begin{array}{l}\text { No. of } \\
\text { seeds/capsule(Mean } \\
\pm \text { S.E.) }\end{array}$ & $\begin{array}{l}\text { 100-seed } \\
\text { weight }(\text { gm }) / \\
\text { plant } \\
(\text { Mean } \pm \text { S.E.) }\end{array}$ & $\begin{array}{l}\text { Seed yield }(\mathrm{gm}) / \\
\text { Plant } \\
(\text { Mean } \pm \text { S.E. })\end{array}$ \\
\hline Control & $36.57 \pm 2.79$ & $2.27 \pm 0.02$ & $40.88 \pm 0.83$ & $0.270 \pm 0.005$ & $3.92 \pm 0.36$ \\
\hline Viridis & $3.47 \pm 0.28$ & $1.61 \pm 0.05$ & $17.76 \pm 1.55$ & $0.270 \pm 0.001$ & $0.19 \pm 0.05$ \\
\hline Broad leaf & $75.50 \pm 6.84$ & $2.30 \pm 0.05$ & $42.70 \pm 1.61$ & $0.263 \pm 0.005$ & $4.43 \pm 0.21$ \\
\hline Thick leaf & $55.20 \pm 8.11$ & $2.24 \pm 0.03$ & $43.27 \pm 0.88$ & $0.233 \pm 0.003$ & $4.73 \pm 0.93$ \\
\hline Unforked narrow leaf & $49.39 \pm 4.31$ & $2.23 \pm 0.03$ & $38.83 \pm 1.03$ & $0.243 \pm 0.005$ & $4.86 \pm 0.40$ \\
\hline Dwarf & $17.38 \pm 1.71$ & $1.73 \pm 0.03$ & $29.45 \pm 0.60$ & $0.253 \pm 0.003$ & $1.13 \pm 0.17$ \\
\hline Diffused branching & $62.58 \pm 6.27$ & $2.43 \pm 0.02$ & $39.47 \pm 1.41$ & $0.217 \pm 0.003$ & $3.69 \pm 0.56$ \\
\hline Funnel & $53.25 \pm 5.01$ & $2.12 \pm 0.04$ & $41.90 \pm 1.86$ & $0.236 \pm 0.005$ & $3.00 \pm 0.49$ \\
\hline Cluster flower & $60.67 \pm 7.23$ & $2.08 \pm 0.05$ & $44.00 \pm 0.93$ & $0.233 \pm 0.005$ & $4.71 \pm 0.79$ \\
\hline Early flowering & $36.13 \pm 2.92$ & $2.19 \pm 0.01$ & $46.73 \pm 0.82$ & $0.297 \pm 0.003$ & $4.50 \pm 0.35$ \\
\hline Late flowering & $45.57 \pm 5.10$ & $2.10 \pm 0.02$ & $40.74 \pm 1.10$ & $0.197 \pm 0.11$ & $2.66 \pm 0.48$ \\
\hline Small flower & $33.96 \pm 3.21$ & $2.37 \pm 0.33$ & $41.77 \pm 0.68$ & $0.247 \pm 0.01$ & $3.09 \pm 0.38$ \\
\hline White flower & $21.67 \pm 2.70$ & $1.85 \pm 0.35$ & $22.62 \pm 0.52$ & $0.227 \pm 0.003$ & $1.62 \pm 0.42$ \\
\hline Globular fruit & $33.00 \pm 5.22$ & $1.83 \pm 0.03$ & $47.31 \pm 2.47$ & $0.227 \pm 0.003$ & $1.93 \pm 0.55$ \\
\hline Nonshattering capsule & $26.87 \pm 1.87$ & $2.19 \pm 0.02$ & $36.95 \pm 0.73$ & $0.283 \pm 0.005$ & $1.85 \pm 0.20$ \\
\hline Elongated fruit & $36.20 \pm 8.08$ & $2.82 \pm 0.02$ & $51.95 \pm 2.41$ & $0.286 \pm 0.003$ & $3.92 \pm 1.05$ \\
\hline $\begin{array}{l}\text { Reddish brown seed } \\
\text { coat I }\end{array}$ & $17.20 \pm 1.42$ & $1.80 \pm 0.02$ & $33.09 \pm 1.11$ & $0.243 \pm 0.01$ & $0.80 \pm 1.10$ \\
\hline $\begin{array}{l}\text { Reddish brown seed } \\
\text { coat II }\end{array}$ & $26.36 \pm 3.12$ & $1.93 \pm 0.03$ & $35.83 \pm 1.72$ & $0.263 \pm 0.005$ & $1.84 \pm 0.35$ \\
\hline $\begin{array}{l}\text { Dark Reddish brown } \\
\text { seed coat I }\end{array}$ & $36.95 \pm 1.59$ & $1.85 \pm 0.02$ & $36.99 \pm 0.74$ & $0.213 \pm 0.003$ & $2.06 \pm 0.18$ \\
\hline $\begin{array}{l}\text { Dark Reddish brown } \\
\text { seed coat II }\end{array}$ & $22.26 \pm 2.09$ & $1.94 \pm 0.02$ & $34.98 \pm 0.90$ & $0.293 \pm 0.003$ & $1.88 \pm 0.24$ \\
\hline Bold seeded & $28.19 \pm 2.60$ & $2.10 \pm 0.02$ & $35.56 \pm 0.78$ & $0.307 \pm 0.005$ & $1.44 \pm 0.15$ \\
\hline Large seeded & $29.52 \pm 2.57$ & $2.19 \pm 0.02$ & $41.14 \pm 0.85$ & $0.307 \pm 0.003$ & $2.22 \pm 0.26$ \\
\hline C.D. at $5 \%$ level & 17.80 & 0.50 & 6.51 & 0.003 & 2.22 \\
\hline
\end{tabular}

Although viridis mutant plants possess smaller distance from base to first branching, the height of the plants are extremely reduced (37.77 $\mathrm{cm} \pm 1.89)$ with less number of branches yielding lower number of capsules and seeds. Viridis mutant may also be attributed as dwarf II. Both number of capsules per plant and number of capsules on the main axis are enhanced significantly than control in broad leaf and thick leaf mutants; however, significantly high number of capsules per plant is evidenced in diffused branching and cluster flower mutants. As compared to control, capsule length and seeds per capsule are increased significantly in elongated fruit, and in globular and elongated fruit mutants respectively. Hundred seed weight in 
control is noted to be $0.27 \mathrm{gm} \pm 0.005$ and it varies significantly among the mutant plant types excepting viridis. As compared to control, bold seeded, large seeded, early flowering and dark reddish brown seed coat II plant types are with higher 100-seed weight; while late flowering mutants demonstrate lower 100seed weight. Although the mean values for seed yield of the mutant plant types do not show significant enhancement over control, the upper range limit of thick leaf, unforked narrow leaf, small flower and cluster flower mutants is found to increase markedly than control.

The macromutants evolved may be classified into 3 groups : (a) can be directly used in sesame breeding as genetic / morphological (white flower, viridis, seed coat colour mutants, dwarf, unforked narrow leaf and small flower) markers not withstanding the utmost significance of early flowering and non shattering capsule mutants in such breeding. (b) used after selection after minimization of flower, capsule and seed sterilities - broad leaf, thick leaf, globular fruit ,elongated fruit ,bold seeded , large seeded ,cluster flower ,diffused branching and funnel and (c) used after intercrossing among the mutant lines followed by selection - all the mutants may be under this category.

The mutants correspond very closely with the ideotype being looked for in the crop. The yielding ability in the mutants may be better with improved agronomic managements. Further, intermating among the mutant lines followed by rigorous selection may give rise to more desirable plant types of interest in sesame.

\section{CONCLUSION}

Quantitative analysis made in 22 plant types (control and 21 true breeding macromutants) for different economic traits at $\mathrm{M}_{4}$ demonstrated that none of the mutant is superior to control for all traits under study but few of them show betterment in some traits which open up the possibility of raising more desirable plant types through intercrossing followed by selection.

\section{ACKNOWLEDGEMENT}

Author is grateful to Prof. Animesh Kumar Datta, Department of Botany, Kalyani University for his valuable guidance and continuous support.

\section{REFERENCES}

1. Trivedi KP. Dhanwantari Vanausidhi Visesank Part III, Dhanwantari Karyalaya, Aligarh. 1965.

2. Chopra RN. Indigenous Drugs of India. $2^{\text {nd }}$ Edn. U.N. Dhur and $\operatorname{Sons}(\mathrm{P})$ Ltd., Calcutta1968; p.608.

3. Morton JF. Mucilaginous plants and their uses in medicine. J Ethnopharmacology 1990; 29: 245-66.

4. Banerjee HT, Das M and Bhattcharjee TK. B-67 is the til for sandy loams of West Bengal. Indian Fmg. 1966; 16: 9-11.

5. Sengupta $\mathrm{K}$ and Chatterjee SD. A review on genetical and breeding work in different oil seed crops at Pulses and Oilseed Research Station, West Bengal. Pulses and Oilseed in West Bengal 1982; p. 149-158.

6. Ghosh BK, Datta AK, Das A and Mandal A. Induced macromutation in Andrographis paniculata (Burn. F.) Nees. Int. J. Res. Ayurveda Pharm. 2012; 3(4):604-10.

7. Maity $S$ and Datta AK. Induced viable macromutation in Corchorus olitorious L. J Phytol Res 2009; 22: 43-46.

8. Dubey PK and Datta AK. Induced mutagenesis in Abelmoschus moschatus (L.) Medik. International Research Journal of Pharmacy 2014; 3(5):432-35.

9. Sengupta $S$ and Datta AK. Desirable Macromutants Induced by chemical mutagenesis in sesame (Sesamum indicum L.). Cytologia 2004; 69(3): 291-95.

10. Sengupta $S$ and Datta AK. Induced narrow leaf mutants of sesame (Sesamum indicum L.). Indian J Genet 2005; 65(1): 59-60.

11. Chowdhury S, Datta AK., Saha A, Sengupta S, Paul R, Maity $S$ and Das A. Traits influencing yield in sesame (Sesamum indicum L.) and multilocational trials of yield parameters in some desirable plant types. Indian Journal of Science and Technology 2010; 3(2):163-66.

\section{Cite this article as:}

Dey Sengupta Sonali et al. Effective macromutants induced through chemical mutagenesis in B-67 cultivar of Sesamum indicum L. Int. J. Res. Ayurveda Pharm. 2017;8(3):96-98 http://dx.doi.org/10.7897/2277-4343.083151

Disclaimer: IJRAP is solely owned by Moksha Publishing House - A non-profit publishing house, dedicated to publish quality research, while every effort has been taken to verify the accuracy of the content published in our Journal. IJRAP cannot accept any responsibility or liability for the site content and articles published. The views expressed in articles by our contributing authors are not necessarily those of IJRAP editor or editorial board members. 